University of Nebraska - Lincoln

DigitalCommons@University of Nebraska - Lincoln

Nebraska Cooperative Fish \& Wildlife Research Nebraska Cooperative Fish \& Wildlife Research Unit -- Staff Publications

2005

\title{
Economic Value of Angling at a Reservoir with Low Visitation
}

Christopher J. Chinzinski

Texas Tech University, chris.chizinski@ttu.edu

Kevin L. Pope

Texas Tech University, kpope2@unl.edu

David B. Willis

Texas Tech University

Gene R. Wilde

Texas Tech University

Edwin J. Rossman

U.S. Army Corps of Engineers

Follow this and additional works at: https://digitalcommons.unl.edu/ncfwrustaff

Chinzinski, Christopher J.; Pope, Kevin L.; Willis, David B.; Wilde, Gene R.; and Rossman, Edwin J., "Economic Value of Angling at a Reservoir with Low Visitation" (2005). Nebraska Cooperative Fish \& Wildlife Research Unit -- Staff Publications. 152.

https://digitalcommons.unl.edu/ncfwrustaff/152

This Article is brought to you for free and open access by the Nebraska Cooperative Fish \& Wildlife Research Unit at DigitalCommons@University of Nebraska - Lincoln. It has been accepted for inclusion in Nebraska Cooperative Fish \& Wildlife Research Unit -- Staff Publications by an authorized administrator of DigitalCommons@University of Nebraska - Lincoln. 


\title{
Economic Value of Angling at a Reservoir with Low Visitation
}

\author{
Christopher J. Chizinski* and Kevin L. Pope \\ Wildlife and Fisheries Management Institute, Texas Tech University, \\ Mail Stop 2125, Lubbock, Texas 79409, USA \\ DAVID B. WILLIS \\ Department of Agricultural and Applied Economics, Texas Tech University, \\ Mail Stop 2132, Lubbock, Texas 79409, USA \\ Gene R. WILdE \\ Wildlife and Fisheries Management Institute, Texas Tech University, \\ Mail Stop 2125, Lubbock, Texas 79409, USA \\ EDWIN J. RosSMAN \\ U.S. Army Corps of Engineers, Tulsa, Oklahoma 74127, USA
}

\begin{abstract}
A travel cost model was used to estimate the per-day consumer surplus for anglers at a reservoir (Lake Kemp, Texas) with low visitation. The average per-day consumer surplus for anglers was \$61-122, depending on the wage rate fraction assigned to the opportunity cost of time. Although this consumer surplus value is small, anglers on the numerous smaller public and private water bodies may, in aggregate, generate a majority of the economic value for freshwater angling. Further, the marginal value per dollar spent managing small water bodies is probably large. Arguably, greater attention should be directed toward managing our nation's numerous smaller water bodies.
\end{abstract}

There are over 27 million freshwater anglers in the USA, who fish a total of 440 million days annually (USFWS 2002). Undoubtedly, many of these fishing trips are to large, well-known reservoirs. There have been numerous economic assessments of large reservoirs (Martin et al. 1982; Anderson et al. 1986; Schorr et al. 1995; Thailing and Ditton 2000), large river systems (Sorg and Loomis 1986; Layman et al. 1996), and trophy fisheries (Weithman and Haas 1982; Connelly and Brown 1991; Kerkvleit et al. 2002) in the USA. Despite the importance that these economic assessments provide for the management of large water bodies, little is known about the individual economic value of numerous smaller and lessvisited water bodies. Because of the recreational experience they offer to local visitors, these lessvisited water bodies may have large marginal values per additional dollar spent on management. Fisheries with low visitation tend to be in close proximity to people, and thus travel time and costs are reduced. Additionally, there tends to be less

\footnotetext{
* Corresponding author: chris.chizinski@ttu.edu
}

Received May 30, 2003; accepted June 7, 2004 Published online February 28, 2005 crowding, which is highly valued and a positive motivational factor in choosing small or lessvisited sites (Anderson and Bonsor 1974; Fedler and Ditton 1994). Herein, we use the single-site travel cost (TC) model (Huppert 1989; Whitehead 1992) to report the value of a reservoir fishery with low visitation and comment on the economic importance of fisheries with low visitation rates.

\section{Study Site}

Lake Kemp is a 6,310-ha, multiuse reservoir located on the Wichita River in Baylor County, Texas. The reservoir was constructed in 1923 for flood control and irrigation use. Today, water drawn from Lake Kemp continues to be primarily used by agriculture, industry, and municipalities, but recreational use has become increasingly important. Even though Lake Kemp is a public water body, site access is privately controlled. The W. T. Waggoner Estate owns the property surrounding Lake Kemp, and during 2000 users were charged US $\$ 20$ for a daily entrance pass, $\$ 55$ for a $3-d$ pass, and $\$ 200$ for an unlimited-visit annual pass. In addition to selling visitation passes, the W. T. Waggoner Estate leases lakeshore property under a long-term contractual agreement to individuals who are allowed to build cabins on the leased prop- 
erty. All cabin owners are required to buy an annual pass. Guests of cabin owners are allowed to enter the property at no cost. Many cabin owners have access to the reservoir by private ramps, boat docks, or boat garages, whereas others rely on the public boat ramps. Visitors use the reservoir for recreational activities that include boating, swimming, and fishing. Fish species commonly targeted by anglers include blue catfish Ictalurus furcatus, channel catfish I. punctatus, largemouth bass $\mathrm{Mi}$ cropterus salmoides, spotted bass M. punctulatus, striped bass Morone saxatilis, white bass M. chrysops, and white crappies Pomoxis annularis.

\section{Methods}

We developed a survey instrument for conducting face-to-face interviews at Lake Kemp's public boat ramps. On-site interviews were conducted from 0800 to 1800 hours (times of public access) from 25 May 2000 to 25 May 2001. During summer (25 May to 15 August 2000), surveys were conducted daily on weekends and holidays and at the beginning (Monday-Wednesday) or the end (Wednesday-Friday) of each weekday period at all usable public boat ramps. For the remainder of the year, sampling occurred on two randomly selected weekends and one randomly selected weekday each month. Lake Kemp has six primary boat ramps with three entrances: Pony Creek, Moonshine, and Flippin Creek. Because of low water levels, only the Moonshine boat ramp was usable from June 2000 to February 2001; thus, all faceto-face interviews during this period were conducted at that ramp. During this period, most private docks and ramps were also unusable. When water levels rose and other public boat ramps became usable, a spot check was periodically performed to determine use and conduct surveys. Additional surveying occurred at the Hotel Neck and Black Bass boat ramps when they became usable in March 2001. Our sample design ensured that we had a comprehensive sample of all recreational users during May 2000 through May 2001.

Information on party size, date, time, and recreational activity (i.e., angling, boating, or other) was recorded for all boat ramp users. Face-to-face interviews with one individual per party were used to collect data on user activities and expenditures. Expenditure data were collected in three categories: lodging costs, transportation costs, and recreational costs (e.g., bait, boat fuel, and suntan lotion). Additional survey data were collected on reservoir usage (e.g., number and duration of visits in the past 12 months and number of years the respondent visited Lake Kemp) and demographic characteristics of respondents (e.g., age, educational attainment, and income).

The TC model is commonly used to establish the recreational value of water resources (Bockstael 1995; Loomis 2003). The technique uses trip expenditures and the value of travel time as an estimate for the price of site admission. Information on the annual number of trips taken and individual per-trip TC is subsequently combined with other explanatory variables, such as income, opportunity cost of recreating, age, family size, and educational attainment, to construct the TC demand curve. Under the assumption that a visitor would respond to either the establishment of an on-site access fee or an increase in an existing onsite access fee in exactly the same way as to an increase in trip TC, a consumer surplus estimate of the net benefit accruing to the visitor can be derived from the estimated demand curve. For a given individual, the consumer surplus measure is calculated as the maximum value an individual would pay to visit the site less the visitor's TC expenses.

Haab and McConnell (2002) noted that it is inappropriate to mix 1-d and 2-d trips to a site within the same TC demand model without further model specification. Given that trip length varied from 1 to $4 \mathrm{~d}$ and one-fourth of the trips to Lake Kemp were multi-day trips, the per-trip TC estimates were converted to an angling day basis. The TC variable was estimated on a per-day, per-individual expenditure basis as

$$
\begin{aligned}
\mathrm{TC}= & \text { VehicleC }+ \text { PassC }+ \text { RecC } \\
& + \text { TravOC }+ \text { RecOC }
\end{aligned}
$$

where

$$
\begin{aligned}
\text { VehicleC }= & \text { transportation cost } \\
\text { PassC }= & \text { entrance fee } \\
\operatorname{RecC}= & \text { recreational expense } \\
\text { TravOC }= & \text { opportunity cost of travel time } \\
\text { RecOC }= & \text { opportunity cost of on-site recreation } \\
& \text { time }
\end{aligned}
$$

Vehicle cost (VehicleC) was estimated by multiplying round-trip mileage by a standardized permile vehicle operation cost estimate for the specific type of vehicle driven. Per-mile vehicle operation cost estimates were obtained from the U.S. Department of Transportation database (USDOT 
1998) for sedans, pickups, sport-utility vehicles, minivans, and full-size vans. Calculated per-trip vehicle cost was subsequently divided by group size and trip length for purposes of expressing VehicleC on a per-individual, per-day basis. Perindividual, per-day entrance pass cost (PassC) was estimated as the cost of the pass purchased $(\$ 20$ for a daily pass, $\$ 55$ for a 3-d pass, and $\$ 200$ for an annual pass) divided by average group size and number of days the pass was used. Per-day, perindividual recreational expense $(\mathrm{RecC})$ was calculated by dividing total reported trip expenses by party size and trip length in days.

The opportunity cost of time (Cesario 1976; Feather and Shaw 1999) component (TravOC + $\mathrm{RecOC}$ ) of the TC calculation explicitly recognizes that time is a scarce resource that, if saved, could be employed elsewhere. The failure to account for the opportunity cost of time biases the TC coefficient upward and thus biases the consumer surplus estimate downward (Cesario and Knetsch 1970). An accurate measure of the TC variable must account for both the opportunity cost of travel time and the opportunity cost of the time engaged in the recreational experience. One common means of determining the opportunity cost of time is to value it as some fraction of the hourly wage rate. However, the wage rate fraction selected can substantially influence the consumer surplus estimate, and thus there is much controversy surrounding the fraction of the hourly wage rate that should be used to value the opportunity cost of travel and recreation time (e.g., Cesario 1976; Bishop and Heberlein 1980; Bowker et al. 1996). Traditionally, a fraction ranging from $25 \%$ to $100 \%$ of each individual's hourly wage rate has been used as the opportunity cost of time (e.g., Cesario 1976; Bowker et al. 1996; Layman et al. 1996; Buchli et al. 2003). Determination of the appropriate wage rate fraction is controversial because the value used tends to be governed by statistical fit and not economic theory. An alternative approach to deriving the opportunity cost of time is to utilize economic theory and directly estimate a hedonic value (Smith et al. 1983) or shadow value (Feather and Shaw 1999) for the opportunity cost of time. However, these alternative estimation approaches require large sample sizes and strong relationships between individuals' demographics and wage rate. Assessments of low-use fisheries are inherently limited by small sample size, which limits the applicability of these newer methods. Thus, we estimated total opportunity cost as the sum of time spent fishing (RecOC) and traveling to and from the lake (TravOC) multiplied by the appropriate opportunity cost of time. In this analysis, we calculated four alternative hourly values for an individual's opportunity cost of time. These four opportunity cost values were derived by multiplying each individual's hourly wage rate by each of the following four wage rate fractions: 25, 33, 50 , and $100 \%$. An individual's hourly wage rate was estimated by dividing annual income by 2,000 work hours. We assumed that fishing time was 8 $\mathrm{h} / \mathrm{d}$ because we did not specifically ask respondents how many hours they fished per day. Roundtrip distance was calculated by doubling the mileage between the zip code of origin and the zip code at Lake Kemp (76380) by use of ZIPFIP software (ERS 1997). Round-trip travel distance provided a basis for calculating travel time and estimating trip transportation expenditure.

Income and education levels were used as explanatory variables in our TC model. Income of the respondents (INC) was the midpoint of their categorized 1999 income divided by $\$ 1,000$ (7.5 for $<\$ 10,000 ; 15$ for $\$ 10,000-19,999 ; 25$ for $\$ 20,000-29,999 ; 35$ for $\$ 30,000-39,999 ; 45$ for $\$ 40,000-49,999 ; 55$ for $\$ 50,000-59,999 ; 65$ for $\$ 60,000-69,999 ; 75$ for $\$ 70,000-79,999 ; 90$ for $\$ 80,000-99,999$; and 120 for $\geq \$ 100,000)$. Educational attainment of respondents (EDU) was the estimated years of schooling completed ( 8 for $\leq 8$ years; 10 for some high school; 12 for high school graduate or equivalent; 14 for some college or technical school; 16 for bachelor's degree or equivalent; and 18 for graduate or professional degree).

The single-site TC demand curve was specified as an untruncated count model (Hellerstein and Mendolsohn 1993) based on the number of days that each surveyed individual visited Lake Kemp in the prior 12 months. A single-site TC demand curve was specified for two reasons. First, all surveyed individuals reported that their trip was a single-site trip. Secondly, only one surveyed individual stated that he had access to a substitute fishing site. An average per-day consumer surplus was derived by integrating under the estimated demand curve for days with respect to the aggregate TC variable. The TC demand curve was statistically estimated by use of the negative binomial form of the Poisson TC model with respect to TC (Englin and Shonkwiler 1995). The Poisson TC model is

$$
\lambda_{i}=e^{\beta_{x}},
$$


where $\lambda_{i}$ is the number of days per year and $\beta_{x}$ is the function influencing visitation rate. Integrating this model with respect to the proxy price variable, $\mathrm{TC}$, where the lower limit of integration is individual $i$ 's current TC and the upper limit of integration is infinity, an estimate of total consumer surplus accruing to individual $i$ visiting the site on $\lambda_{i}$ days per year is derived. This estimate has the following integral solution:

$$
\int \lambda_{i} d \mathrm{TC}=\frac{\lambda_{i}}{\beta_{\mathrm{TC}}},
$$

where TC is the sum of TCs including out-of-pocket expenses and opportunity cost of time, and $\beta_{\mathrm{TC}}$ is the coefficient of the TC variable. Dividing the result by $\lambda_{i}$ produces the per-day consumer surplus estimate for individual $i$.

The statistical problems associated with endogenous stratification (Loomis 2003) and truncation (Bloom and Killingsworth 1985) were not issues in this analysis. Endogenous stratification was not a problem because we sampled frequently over the year and therefore probably missed very few users. Truncation issues were disregarded because this analysis focused on estimating the annual use value to current users, not the general public.

\section{Results}

\section{Party Characteristics}

From 25 May 2000 to 25 May 2001, 177 parties (597 individuals) were interviewed. Ninety-four percent of the interviews occurred at the Moonshine boat ramp, 5\% at the Hotel Neck boat ramp, and the remaining $1 \%$ at the Black Bass boat ramp. Of the parties contacted, $133(75 \%)$ agreed to a face-to-face survey. One-hundred seventeen of the 133 face-to-face surveys were usable. Most discarded surveys were excluded because participants were unwilling to report their household income, which was an important and significant variable in our final TC demand model.

Lake Kemp users were categorized as anglers if a majority $(>50 \%)$ of their recreational activity was angling. Forty-one acceptable surveys were completed by anglers, which represented 208 total anglers for the year. The number of anglers contacted was small, but we believe it is a comprehensive representation of all Lake Kemp anglers. Expansion of our survey to the entire year (May 2000 to May 2001) indicates that we contacted at least $97 \%$ of the anglers who visited Lake Kemp during daylight (i.e., open gate hours). This estimate was derived from historical data visits and entry day passes sold by the W. T. Waggoner Estate for 1999 and 2000. Mean number of trips per year to Lake Kemp by anglers was 15.8 ; the mean duration per trip was $1.65 \mathrm{~d}$. Most anglers were male, were 40-49 years old, had a high-school education, and had a 1999 household income of $\$ 50,000-59,000$. Fifty-nine percent of anglers purchased an annual entrance pass. Mean fishing party size was 2.7 individuals, and the mean distance traveled to visit Lake Kemp was $228.5 \mathrm{~km}$ (142 mi) round-trip.

\section{Travel Cost}

The best fitting single-site TC model (Huppert 1989; Whitehead 1992) for annual days spent fishing at Lake Kemp, as determined by the loglikelihood function value, was

$$
\text { Days }=e^{[0.7011-0.0165(\mathrm{TC})+0.0253(\mathrm{INC})+0.1912(\mathrm{EDU})]},
$$

where $e$ is the exponential function; the hourly opportunity cost of time used in the construction of the TC variable was $25 \%$ of the hourly wage rate (Table 1$)$. The overall model was highly significant $\left(\chi^{2}=479\right.$, df $\left.=5, P=0.0000\right)$, and all parameter estimates except for the constant term were significant $(P<0.05)$. However, the same was true for the three other estimated TC models, which differed from each other only in how the opportunity cost of time was calculated. Though not reported, the Davidson-MacKinnon nonnested test (Davidson and MacKinnon 1981) for variable specification did not detect a significant difference among the four specifications of the TC variable in terms of explaining the number of days annually spent at Lake Kemp. Consistent with consumer demand theory, the annual number of days spent fishing at Lake Kemp decreased as the per-day cost of site access (i.e., TC) increased. As expected, fishing at Lake Kemp was an income normal activity: the annual number of days spent fishing increased with the individual's income. Likewise, educational attainment was also positively related to annual days on site. Despite the fact that the wage rate fraction used to calculate the hourly opportunity cost of time minimally impacted the overall model goodness of fit, the wage rate fraction affected the per-day calculation of mean consumer surplus (Yen and Adamowicz 1993; Englin and Shonkwiler 1995; Bowker et al. 1996). The mean consumer surplus value for Lake Kemp visitors was $\$ 61, \$ 64, \$ 73$, and $\$ 122$ per day per individual, respectively, for the $25,33,50$, and $100 \%$ wage rate fractions used to estimate the hourly opportunity cost of time. 
TABLE 1.-Model parameters, SEs, $P$-values, and mean characteristics of 41 respondents used to estimate economic value (i.e., consumer surplus) of recreational angling at Lake Kemp, Texas, based on the count visitation travel cost (TC) method. Visitation rates were assumed to follow a negative binomial distribution. Models differed in the fraction of the wage rate $(25-100 \%)$ that was used to estimate the opportunity cost of travel and recreation time (a component of the TC variable).

\begin{tabular}{lrrrr}
\hline $\begin{array}{l}\text { Model and } \\
\text { variable }\end{array}$ & \multicolumn{1}{c}{ Parameter } & SE & \multicolumn{1}{c}{$P$} & Mean \\
\hline 25\% of wage rate & & & & \\
Intercept & 0.7011 & 1.1397 & 0.5385 & \\
Travel cost & -0.0165 & 0.0044 & 0.0002 & 115.28 \\
Income & 0.0253 & 0.0076 & 0.0009 & 60.40 \\
Education & 0.1912 & 0.0844 & 0.0235 & 13.85 \\
33\% of wage rate & & & & \\
Intercept & 0.6417 & 1.1452 & 0.5752 & \\
Travel cost & -0.0157 & 0.0043 & 0.0002 & 138.67 \\
Income & 0.0304 & 0.0089 & 0.0006 & 60.40 \\
Education & 0.1934 & 0.0850 & 0.0229 & 13.85 \\
50\% of wage rate & & & & \\
Intercept & 0.5368 & 1.1640 & 0.6447 & \\
Travel cost & -0.0137 & 0.0039 & 0.0005 & 188.39 \\
Income & 0.0382 & 0.0112 & 0.0007 & 60.40 \\
Education & 0.1959 & 0.0865 & 0.0235 & 13.85 \\
100\% of wage rate $\mathrm{d}$ & & & & \\
Intercept & 0.3971 & 1.2234 & 0.7455 & \\
Travel cost & -0.0082 & 0.0027 & 0.0026 & 334.63 \\
Income & 0.0441 & 0.0147 & 0.0027 & 60.40 \\
Education & 0.1942 & 0.0903 & 0.0315 & 13.85 \\
\hline
\end{tabular}

a TC model log-likelihood value is $-162.5678(P=0.0000)$.

b TC model log-likelihood value is $-162.6694(P=0.0000)$.

${ }^{\mathrm{c}}$ TC model log-likelihood value is $-163.0985(P=0.0000)$.

d TC model log-likelihood value is $-164.6193(P=0.0000)$.

\section{Discussion}

Low-use fisheries pose a problem for economic valuation. Low sample sizes associated with lessvisited sites limit the statistical methods available, thereby increasing the difficulty of assigning a dollar value. This is especially problematic with the opportunity cost of time. Newer, more robust methods are less useful because small sample sizes limit statistical significance, whereas arbitrary selection of a wage rate percentage can bias the results. For example, the consumer surplus estimate doubles when the opportunity cost of time increases from $25 \%$ of the wage rate to $100 \%$ of the wage rate. Thus, there is a need to develop techniques that will better enable scientists to estimate the economic value of smaller and less-visited water bodies.

Previous economic studies of water-based recreation have emphasized the value of extremely large (>80,000 acres [32,375 ha]) reservoirs or water bodies with national reputations (Weithman and Haas 1982; Anderson et al. 1986; Sorg and Loomis 1986; Schorr et al. 1995; Thailing and Ditton 2000). Such sites typically are unique in the quality of the fishing experiences offered (e.g., trophy fish; Wilde and Pope 2004). However, few economic assessments of smaller fishing reservoirs are available even though these sites are more abundant and probably account for the majority of direct expenditures for recreational angling (Chizinski 2002). For purposes of comparability with prior published research, the estimated individual per-day mean consumer surplus value was multiplied by mean trip length $(1.65 \mathrm{~d})$ to derive a mean per-trip consumer surplus value. This conversion assumes that the estimated per-day surplus is constant over the entire trip. Depending on the opportunity cost of time, the mean per-individual consumer surplus value for recreational angling at Lake Kemp ranged from $\$ 100$ to $\$ 201$ per trip, which is toward the lower end of the range of estimates for better-known fisheries $(\$ 8-\$ 1,200$ per trip, adjusted for inflation to year-2000 dollars by use of the consumer price index [USDL 2002]). Sites with national reputations tend to have greater per-trip consumer surplus values because a large number of visitors are willing to travel great distances to visit these unique sites (Fix and Loomis 1997). Most (77\%) of the Lake Kemp anglers traveled relatively short distances to reach the reservoir (i.e., $<113 \mathrm{~km}[70 \mathrm{mi}]$ ). Thus, the per-day and hence per-trip consumer surplus generated by recreational angling at Lake Kemp was limited by the small number of anglers and short distances traveled, particularly because this reservoir is not regionally known for angling.

Economic assessments are an important tool in fisheries management and can be used as a valuable framework for prioritizing management activity and expenditures. We believe that expenditures of effort and monies for recreational fishery management should be allocated to individual water bodies based on their marginal economic value of recreational angling. For example, in Texas there are 728 public water bodies less than 405 ha (1,000 acres), 112 reservoirs between 405 and 8,094 ha (20,000 acres), and 19 reservoirs larger than 8,094 ha. Current management of these water bodies is based on reservoir surface area; angler visitation and expenditures seldom factor into the allocation of management effort. There is an important need to further investigate this management concern that may require a greater shift in management effort in Texas and the rest of the USA toward smaller reservoirs. 


\section{Acknowledgments}

We thank F. Martinez, Jr., K. R. Offill, J. P. Shuck, and S. H. Sebring for their assistance with surveys at Lake Kemp. R. B. Ditton provided assistance with the development of the questionnaire. B. W. Durham, R. M. Rejesus, D. W. Willis, and three anonymous reviewers provided valuable comments that greatly improved this manuscript. We thank the W. T. Waggoner Estate for access to Lake Kemp. Financial support was provided by the U.S. Army Corps of Engineers through the U.S. Geological Survey grant 1434-HQ-97-RU-01570. The views expressed herein are those of the authors and not those of the U.S. Army Corps of Engineers. Reference to trade names does not imply endorsement by the U.S. Government. This is manuscript number T-9-1019 of the College of Agricultural and Natural Resources, Texas Tech University.

\section{References}

Anderson, F. J., and N. C. Bonsor. 1974. Allocation, congestion, and the valuation of recreation resources. Land Economics 50:51-57.

Anderson, R. S., C. J. Schwinden, and J. A. Leitch. 1986. Regional economic impact of the Devils Lake fishery. Fisheries 11(5):14-17.

Bishop, R. C., and T. A. Heberlein. 1980. Simulated markets, hypothetical markets, and travel cost analysis: alternative methods of estimating outdoor recreation demand. Wisconsin Agriculture Experimental Station, Bulletin 187, Madison.

Bloom, D. E., and M. R. Killingsworth. 1985. Correction for truncation bias caused by a latent truncation variable. Journal of Econometrics 27:131-135.

Bockstael, N. 1995. Travel cost models. Pages 655-671 in D. Bromley, editor. Handbook of environmental economics. Blackwell Scientific Publications, Cambridge, Massachusetts.

Bowker, J. M., D. B. K. English, and J. A. Donavan. 1996. Toward a value for guided rafting on southern rivers. Journal of Agricultural and Applied Economics 28:423-432.

Buchli, L., M. Filippini, and S. Banfi. 2003. Estimating the benefits of low-flow alleviation in rivers: the case of the Ticino River. Applied Economics 35: 585-590.

Cesario, F. J. 1976. Value of time in recreational benefit studies. Land Economics 52:32-41.

Cesario, F. J., and J. L. Knetsch. 1970. Time bias in recreation benefit studies. Water Resources Research 6:700-704.

Chizinski, C. J. 2002. Evaluation of water quality characteristics on water-based recreation at Lake Kemp, Texas. Master's thesis. Texas Tech University, Lubbock.

Connelly, N. A., and T. L. Brown. 1991. Net economic value of the freshwater recreational fisheries of New
York. Transactions of the American Fisheries Society 120:770-775.

Davidson, R., and J. G. MacKinnon. 1981. Several tests of model specification in the presence of alternative hypotheses. Econometrica 49:781-793.

Englin, J., and J. S. Shonkwiler. 1995. Estimating social welfare using count data models: an application to long-run recreation demand under conditions of endogenous stratification and truncation. Review of Economics and Statistics 77:104-112.

ERS (U.S. Department of Agriculture, Economic Research Service). 1997. ZIPFIP. ERS, Washington, D.C.

Feather, P., and W. D. Shaw. 1999. Estimating the cost of leisure time for recreation demand models. Journal of Environmental Economics and Management 38:49-65.

Fedler, A. J., and R. B. Ditton. 1994. Understanding angler motivations in fisheries management. Fisheries 19(4):6-13.

Fix, P., and J. B. Loomis. 1997. The economic benefits of mountain biking at one of its meccas: an application of the travel cost method to mountain biking in Moab, Utah. Journal of Leisure Research 29:342352 .

Haab, T. C., and K. E. McConnell. 2002. Valuing environmental and natural resources: the econometrics of nonmarket evaluation. Edward Alger Press, Cheltenham, UK.

Hellerstein, D., and R. Mendolsohn. 1993. A theoretical foundation for count models. American Journal of Agricultural Economics 75:604-611.

Huppert, D. D. 1989. Measuring the value of fish to anglers: application to central California anadromous species. Marine Resource Economics 6:89108.

Kerkvleit, J., C. Nowell, and S. Lowe. 2002. The economic value of the Greater Yellowstone's blue-ribbon fishery. North American Journal of Fisheries Management 22:418-424.

Layman, R. C., J. R. Boyce, and K. R. Criddle. 1996. Economic valuation of the Chinook salmon sport fishery of the Gulkana River, Alaska, under current and alternate management plans. Land Economics 72:113-128.

Loomis, J. L. 2003. Travel cost demand model based river recreation benefit estimates with on-site and household surveys: comparative results and a correction procedure. Water Resources Research 39(4): Article 1105.

Martin, W. E., F. H. Bollman, and R. L. Gum. 1982. Economic value of Lake Mead fishery. Fisheries 7(6):20-24.

Schorr, M., S. J. Sah, D. F. Schreiner, M. R. Meador, and L. G. Hill. 1995. Regional economic impact of the Lake Texoma (Oklahoma and Texas) striped bass fishery. Fisheries 20(5):14-18.

Smith, V. K., W. H. Desvousges, and M. P. McGivney. 1983. The opportunity cost of time in recreational demand models. Land Economics 59:259-277.

Sorg, C. F., and J. B. Loomis. 1986. Economic value of Idaho sport fisheries, with an update on valuation 
techniques. North American Journal of Fisheries Management 6:494-503.

Thailing, C. E., and R. B. Ditton. 2000. Characteristics, participation patterns, attitudes, management preferences, expenditures, and economic impact of Toledo Bend Reservoir anglers: Texas and Louisiana. Texas A\& M University, Human Dimensions of Fisheries Laboratory Report HD-616, College Station.

USDL (U.S. Department of Labor). 2002. Consumer price index. USDL, Report USDL-03-15, Washington, D.C.

USDOT (U.S. Department of Transportation). 1998. Our nation's highways: selected facts and figures. USDOT, Federal Highway Administration, Office of Highway Information Management, Report FWHAPL-98-015, Washington, D.C.

USFWS (U.S. Fish and Wildlife Service). 2002. 2001 national survey of fishing, hunting, and wildlifeassociated recreation. USFWS, Report FHW/01NAT, Washington, D.C.

Weithman, A. S., and M. A. Haas. 1982. Socioeconomic value of the trout fishery in Lake Taneycomo, Missouri. Transactions of the American Fisheries Society 111:223-230.

Wilde, G. R., and K. L. Pope. 2004. Relationship between lake-record weights of fishes and reservoir area and growing season. North American Journal of Fisheries Management 24:1025-1030.

Whitehead, J. C. 1992. Benefits of quality changes in recreational fishing: a single-site travel cost approach. Journal of Environmental Systems 21:357364.

Yen, S. T., and W. L. Adamowicz. 1993. Statistical properties of welfare measures from count-data models of recreation demand. Review of Agricultural Economics 15:203-215. 